\title{
Measurements of $\mathrm{O}_{3}, \mathrm{NO}_{2}$ and $\mathrm{BrO}$ during the INDOEX campaign using ground based DOAS and GOME satellite data
}

\author{
A. Ladstätter-Weißenmayer, H. Altmeyer, M. Bruns, A. Richter, A. Rozanov, V. Rozanov, F. Wittrock, and \\ J. P. Burrows \\ Institute of Environmental Physics, University of Bremen, P.O. Box 330440, D-28334 Bremen, Germany
}

Received: 24 July 2006 - Published in Atmos. Chem. Phys. Discuss.: 26 September 2006

Revised: 13 December 2006 - Accepted: 20 December 2006 - Published: 18 January 2007

\begin{abstract}
The INDian Ocean EXperiment (INDOEX) was an international, multi-platform field campaign to measure long-range transport of air masses from South and SouthEast-(SE) Asia towards the Indian Ocean. During the dry monsoon season between January and March 1999, local measurements were carried out from ground based platforms and were compared with satellite based data. The objective of this study was to characterise stratospheric and tropospheric trace gas amounts in the equatorial region, and to investigate the impact of air pollution at this remote site. For the characterisation of the chemical composition of the outflow from the S-SE-Asian region, we performed ground based dual-axis-DOAS (Differential Optical Absorption Spectroscopy) measurements at the KCO (Kaashidhoo Climate Observatory) in the Maldives $\left(5.0^{\circ} \mathrm{N}, 73.5^{\circ} \mathrm{E}\right)$. The measurements were conducted using two different observation modes (off-axis and zenith-sky). This technique allows the separation of the tropospheric and stratospheric columns for different trace gases like $\mathrm{O}_{3}$ and $\mathrm{NO}_{2}$. These dual-axis DOAS data were compared with $\mathrm{O}_{3}$-sonde measurements performed at KCO and satellite based GOME (Global Ozone Measuring Experiment) data during the intensive measuring phase of the INDOEX campaign in February and March 1999. From GOME observations, tropospheric and stratospheric columns for $\mathrm{O}_{3}$ and $\mathrm{NO}_{2}$ were retrieved. In addition, the analysis of the $\mathrm{O}_{3}$-sonde measurements allowed the determination of the tropospheric $\mathrm{O}_{3}$ amount. The comparison shows that the results of all three measurement systems agree within their error limits. During the INDOEX campaign, mainly background conditions were observed, but in a single case an increase of tropospheric $\mathrm{NO}_{2}$ during a short pollution event was observed from the ground and the impact on the vertical columns was calculated. GOME measurements showed evidence for small tropospheric contributions
\end{abstract}

Correspondence to: A. Ladstätter-Weißenmayer (lad@iup.physik.uni-bremen.de) to the $\mathrm{BrO}$ budget, probably located in the free troposphere and present over long periods of the year. The amounts of $\mathrm{BrO}$ have been investigated by the comparison of satellite pixels influenced by high and low cloud conditions based on GOME data which allows the determination of the detection limit of $3.8 \times 10^{13}$ molecules $\mathrm{cm}^{-2}$ of tropospheric $\mathrm{BrO}$ columns.

\section{Introduction}

The INDOEX project was an international scientific experiment with the main objective to study natural and anthropogenic climate forcing by aerosols and feedbacks on regional and global climate (Ramanathan et al., 2001). INDOEX field studies were carried out over the tropical Indian Ocean, which provides a unique natural laboratory for aerosol studies at the crossing point of pristine air masses from the southern Indian Ocean including Antarctica and rather polluted air masses from the Indian subcontinent. Regional consequences of global warming likely depend on the potentially large cooling effect of aerosols. Therefore, during the intensive field campaign of INDOEX, data were collected from airborne, ship-borne, ground - and satellite based instruments to analyse aerosol composition, atmospheric trace gases, and the long range transport of air pollution from SE Asia towards the Indian Ocean during the dry monsoon (Lelieved et al., 2001). The KCO, established by the Maldives government and the Scripps Institution of Oceanography is located in the tropics $\left(5.0^{\circ} \mathrm{N}, 73.5^{\circ} \mathrm{E}\right)$. The KCO played a central role in the INDOEX campaign (Ramanathan et al., 2001). At $\mathrm{KCO}$ measurements with $\mathrm{O}_{3}$ sondes and in-situ measurements of $\mathrm{O}_{3}$, carbon monoxide (CO), carbon dioxide $\left(\mathrm{CO}_{2}\right)$, methane $\left(\mathrm{CH}_{4}\right), \mathrm{CFCs}$, other chlorinated gases, nitrous oxide $\left(\mathrm{N}_{2} \mathrm{O}\right)$ and sulfur hexafluoride $\left(\mathrm{SF}_{6}\right)$ were carried out alongside meteorological measurements of wind speed and direction, dry air temperature,

Published by Copernicus GmbH on behalf of the European Geosciences Union. 


\section{Zenith-sky-mode}

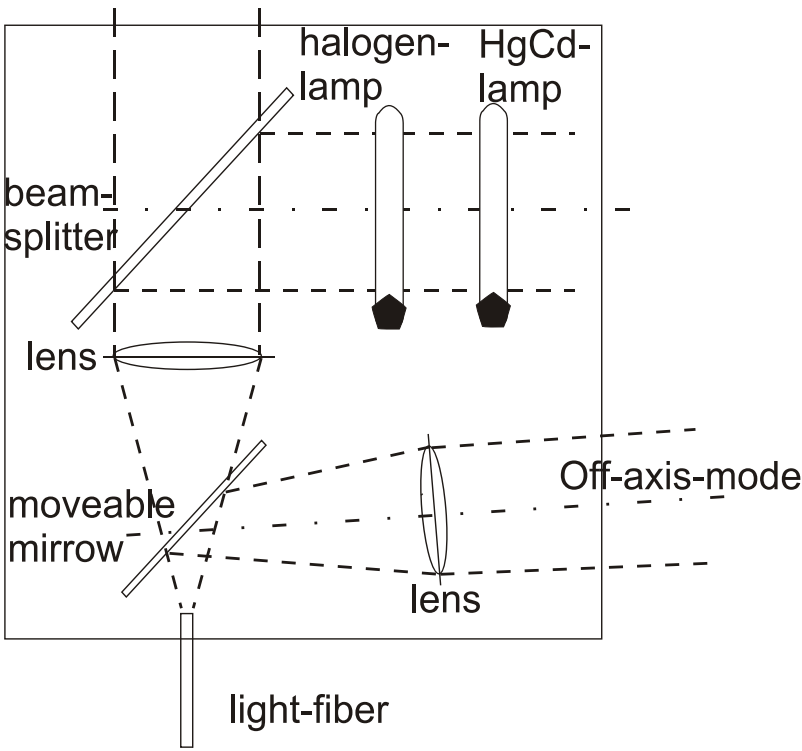

Fig. 1. Experimental setup of the DOAS telescope used in Kaashidhoo from 14 February to 16 March 1999 during the INDOEX campaign.

relative humidity, atmospheric pressure and rain amount during the intensive INDOEX campaign. During INDOEX, the Institute of Environmental Physics and Remote Sensing of the University of Bremen, Germany, performed remote sensing measurements using the technique of dual-axis-DOAS (off-axis and zenith-sky mode) at KCO. This instrument was a precursor of the multi-axis DOAS instrument described in (Wittrock et al., 2004) and (Heckel et al., 2005). Similar set-ups have been developed by other groups (Hoenninger et al., 2004), (Roozendael et al., 2003). Simultaneous measurements of zenith-sky and off-axis scattered sunlight allow to distinguish stratospheric and tropospheric amounts of atmospheric gases. In this case the total and tropospheric column amounts of ozone $\left(\mathrm{O}_{3}\right)$, nitrogen dioxide $\left(\mathrm{NO}_{2}\right)$, as well as tropospheric amounts of $\mathrm{BrO}$ above $\mathrm{KCO}$ have been investigated. The results of our $\mathrm{O}_{3}$ and $\mathrm{NO}_{2}$ measurements were to be compared with those from GOME (Global Ozone Monitoring Experiment) (Burrows et al., 1999). The subject of this contribution is the validation of remotely sensed GOME data with ground based and $\mathrm{O}_{3}$-sonde measurements above the Indian Ocean during INDOEX and also the synergistic use of all these measurements to exploit the advantages of the different methods (such as their different spatial and temporal resolution) to allow the best possible interpretation.

\section{Experimental Set-up}

\subsection{Ground based DOAS measurements}

During the intensive INDOEX campaign, DOAS measurements were carried out at $\mathrm{KCO}$ using two selected viewing geometries (dual technique: zenith and off-axis) (see Fig. 1). The dual-axis-DOAS-instrument is comprised off a Czerny Turner spectrometer (ARC 500, Acton Research Coporation) and a custom made telescope. High temporal resolution was achieved by switching between zenith-sky and $2^{\circ}$ above the horizon direction within a short time interval (typically a few minutes). We can therefore assume essentially no change in the vertical column amount between the two recordings. For the observations at the elevation angle of $2^{\circ}$ (angle between the horizontal direction and the viewing direction of the telescope) the light path through the boundary layer is extended and therefore the sensitivity to the lower atmosphere enhanced compared to the observation of zenith scattered sunlight $\left(90^{\circ}\right)$, which has a comparatively short path through the troposphere. These measurements were carried out each day between sunrise (average over the morning measurements = a.m.-value) and sunset (average over the evening measurements $=$ p.m.-value) in the wavelength region of $327-492 \mathrm{~nm}$ with a spectral resolution of $0.5 \mathrm{~nm}$. For this study, spectra in the wavelength region of 435-481 nm were analysed applying the DOAS technique (Platt, 1994), (Wittrock et al., 2004), (Heckel et al., 2005) to obtain the differential slant column (DSC). The DSC is the difference between the column amount of the absorber integrated along the light path through the atmosphere at the time of measurement (SC) and the absorber amount in the background spectrum $\left(\mathrm{SC}_{0}\right)$. For the background spectrum, a zenith measurement at high sun taken on the same day was used for both zenith-sky and offaxis observations. The absorber amount in the background spectrum $\left(\mathrm{SC}_{0}\right)$ is derived by assuming the mean value of the a.m. and the p.m. values for the vertical columns. A fifth order polynomial was fitted to the spectrum and absorptions by $\mathrm{O}_{3}$ (Burrows et al., 1999), $\mathrm{NO}_{2}$ (Burrows et al., 1998), the oxygen dimer $\mathrm{O}_{4}$ (Greenblatt et al., 1990) as well as $\mathrm{H}_{2} \mathrm{O}$ (Rothman et al., 1992) were taken into account. The effect of Raman scattering (Grainger and Ring, 1962) was compensated by fitting a synthetic Ring spectrum as an additional absorber (Vountas et al., 1998). Total vertical columns of the trace gases $\mathrm{O}_{3}$ and $\mathrm{NO}_{2}$ for the location Kaashidhoo can be derived by the division of the slant columns of the zenith measurements by the air mass factor (AMF). The AMF describes the light path through the atmosphere and is calculated with GOMETRAN/SCIATRAN (Rozanov et al., 1997). Error analysis revealed a maximum relative error of $5 \%$ for the total amount for either trace gas retrieval, taking into account the radiative transfer in the atmosphere for the AMF calculation including the assumed shape of the vertical profile of the absorber, the surface albedo, and the aerosol loading. 
The total vertical column of the trace gases consists of a tropospheric as well as a stratospheric part. Using both observation modes and appropriate AMF calculations, tropospheric vertical columns and/or profiles can be deduced from the measurements (Heckel et al., 2005), (Wittrock et al., 2004), as carried out in this study for the trace gas $\mathrm{O}_{3}$. The analysis of the tropospheric amount of $\mathrm{NO}_{2}$ is based on the results of dual-axis-DOAS measurements combined with model assumptions. The following simplifying assumptions were made for the calculation of tropospheric $\mathrm{NO}_{2}$ : (a) a polluted and well mixed air mass (air masses with higher amounts of $\mathrm{NO}_{2}$ than in the surroundings air) follows the wind from north to south, (b) this air parcel passes both observing modes without any exchange with the environment and (c) the air mass is box shaped with homogenously high amounts of $\mathrm{NO}_{2}$ (see Fig. 2). With these assumptions the analysed air parcel is passing first the off-axis observing mode and then the zenith observing direction (see Fig. 2).

\subsection{GOME and $\mathrm{O}_{3}$-sonde measurements}

GOME was launched in April 1995 onboard the European satellite ERS-2 in a sun-synchronous near polar orbit at a mean altitude of $795 \mathrm{~km}$ for measuring the sunlight scattered from the Earth's atmosphere and/or reflected by the surface in nadir mode in a wavelength region of 240 to $790 \mathrm{~nm}$ with a spectral resolution of $0.2-0.4 \mathrm{~nm}$. The local equator crossing time is 10:30 a.m. With 14 orbits per day, global coverage at the equator is reached after three days for a $960 \mathrm{~km}$ swath width (the size of one GOME ground pixel is $40 \times 320 \mathrm{~km}^{2}$ ) (Burrows et al., 1999). For this study GOME data reprocessed with WFDOAS (Weighting Function Differential Optical Absorption Spectroscopy) Version 1 (Coldewey et al., 2005) and (Weber et al., 2005) were extracted with a maximum distance of $300 \mathrm{~km}$ away from the location of interest to obtain vertical columns of $\mathrm{O}_{3}$. The analysis to derive slant columns of $\mathrm{NO}_{2}$ (Richter and Burrows, 2002) in the $425-450 \mathrm{~nm}$ and of $\mathrm{BrO}$ in the $344-359 \mathrm{~nm}$ wavelength region (Richter et al., 2002) was carried out using the IUP Bremen DOAS algorithm. The retrieval method is similar to that used for ground-based zenith-sky measurements. For the comparisons with ground based DOAS measurements, only GOME lv1-spectra with a maximum distance of $300 \mathrm{~km}$ around Kaashidhoo were extracted. GOME observes both, the troposphere and the stratosphere (Burrows et al., 1999), and in cloudy conditions it is impossible for GOME to detect the exact trace gases amount below the cloud layer. For the comparison of the tropospheric column amounts from GOME with ground based DOAS measurements, only GOME-pixels under cloud free conditions (using measurements with a cloud fraction of less than 0.2 as determined by the FRESCO algorithm (Koelemeijer, et al., 2001)) were included in the analysis. The tropospheric trace gas columns were derived by applying the tropospheric excess method (TEM) or reference sector approach. The

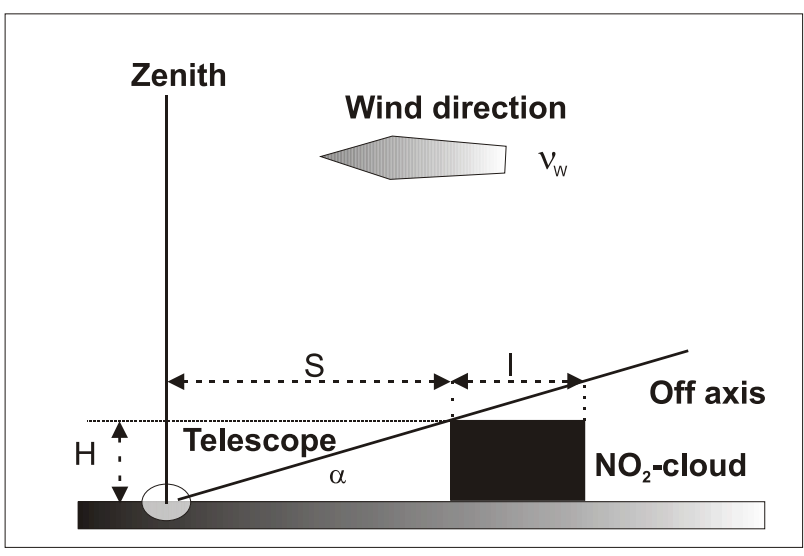

Fig. 2. The conceptual model used for describing a plume with high $\mathrm{NO}_{2}$ amounts as observed with zenith and off axis geometry.

TEM is based on the assumption that the columns of stratospheric trace gases such as $\mathrm{NO}_{2}$ and $\mathrm{O}_{3}$ are approximately constant at a given longitude. This is a large over simplification but appears to work well for tropical and sub tropical conditions for $\mathrm{O}_{3}$ and $\mathrm{NO}_{2}$ and to higher latitudes mainly for $\mathrm{NO}_{2}$. A number of studies have been published focusing on the retrieval of tropospheric $\mathrm{NO}_{2}$ (Leue et al., 2001), (Richter and Burrows, 2002), (Martin et al., 2002) and $\mathrm{O}_{3}$ (Ladstätter-Weißenmayer et al., 2004) from GOME data. The error on the resultant tropospheric $\mathrm{O}_{3}$ is estimated to be 4 DU (Ladstätter-Weißenmayer et al., 2004) and on the tropospheric columns of $\mathrm{NO}_{2}$ approximately $1.5 \times 10^{15}$ molecules $\mathrm{cm}^{-2}$ (Richter and Burrows, 2002) based on GOME data. During the INDOEX campaign in January to March 1999, in addition to the Vaisala radio sondes (Komhyr et al., 1995) 55 electrochemical cell (ECC) ozone soundings (Lobert et al., 2002) and (Thompson et al., 2003) were launched about once per day at approximately 14:00 local time (09:00 Universal Time (UT)) at the KCO by the Scripps Institution of Oceanography. In order to obtain the tropospheric vertical columns of $\mathrm{O}_{3}$, the sonde data were summed up to the height of the tropopause defined in this case study to be at $4 \mathrm{PV}$ (potential vorticity) Units.

\section{Results and Discussion}

\subsection{Total column amounts of $\mathrm{O}_{3}$ and $\mathrm{NO}_{2}$}

The ground based DOAS measurements were used to determine a.m.-, and p.m.-, values for $\mathrm{O}_{3}$ and $\mathrm{NO}_{2}$ total columns. The latter were determined from the observations at SZA between 83 and $90^{\circ}$ in the morning and afternoon. The analysis of the zenith-sky ground based measurements of $\mathrm{O}_{3}$ showed almost no difference between a.m. and p.m. values (Fig. 3a). Indicating that there was no detectable diurnal variation for the vertical columns of $\mathrm{O}_{3}$ during the whole INDOEX 

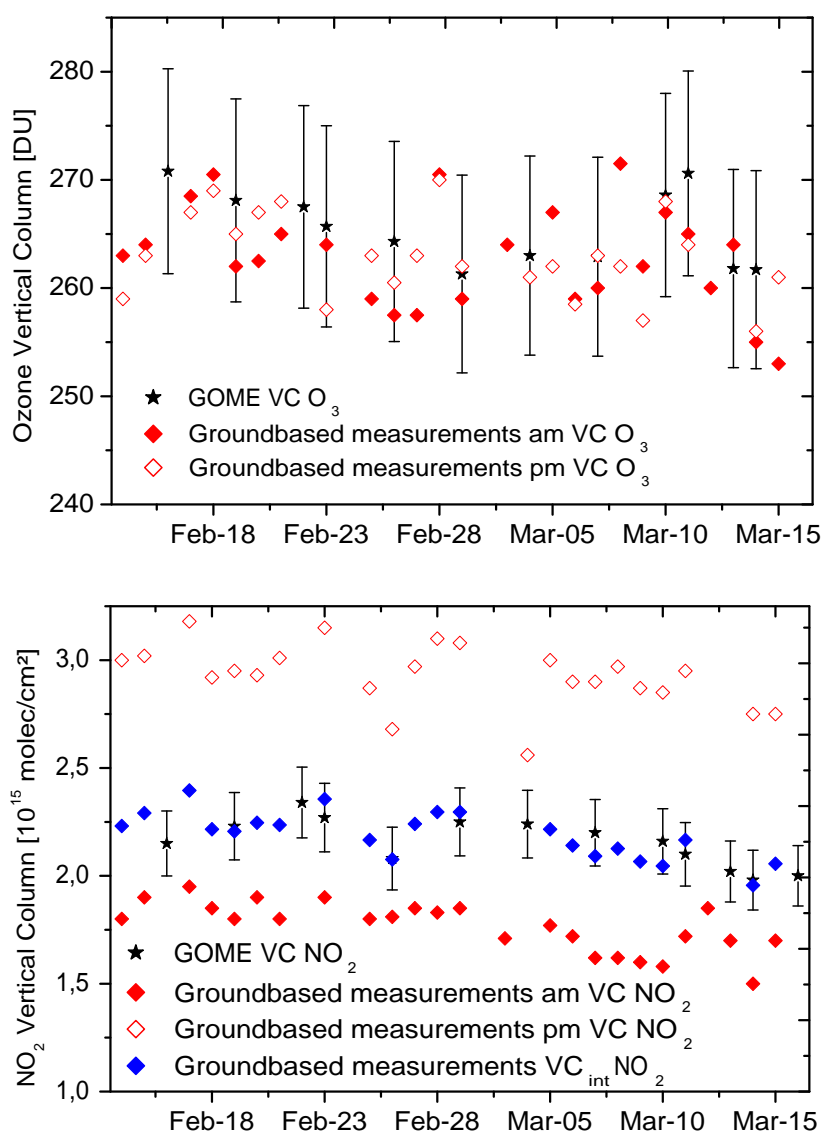

Fig. 3. Total columns of $\mathrm{O}_{3}$ (a) and $\mathrm{NO}_{2}$ (b) measured by the ground based DOAS system and with GOME during the INDOEX campaign from 14 February to 16 March $1999 . \mathrm{VC}_{\text {int }}$ is the groundbased vertical column of $\mathrm{NO}_{2}$ interpolated to the GOME overpass time.(c) Model calculation of the diurnal cycle of $\mathrm{NO}_{2}$ for 20 March 1999 including the measuring time of ground based a.m. and p.m. as well as the overpass time of GOME.

campaign. A mean value of 263 DU (Dobson Units) was determined using both a.m. and p.m. data. Deviations of up to $10 \mathrm{DU}$ from the mean value which can be attributed to the transport of different air masses, are observed. Comparison of these data with the results of satellite based GOME measurements shows agreement within 3\% for the total columns. This value is smaller than the combined errors of the ground based measurements and the satellite based measurements of $5 \%$. Figure $3 \mathrm{~b}$ shows the a.m. and p.m. values for $\mathrm{NO}_{2}$ vertical columns (given in molecules $\mathrm{cm}^{-2}$ ) from the ground based DOAS measurements compared to the GOME results. The difference between the a.m. (around 6:30 a.m.) and the p.m. (around 17:30 p.m.) values of the ground based measurements was significant for $\mathrm{NO}_{2}$. The p.m. values were almost a factor of 1.7 higher than the a.m. values. This behavior is attributed to the photolysis of $\mathrm{N}_{2} \mathrm{O}_{5}$ in the stratosphere. The influence of the diurnal cycle is more intense in the tropics compared to mid-latitudes where the factor is typically 1.4 (Solomon et al., 1987) for ground based measurements. An average $\mathrm{NO}_{2}$ daytime increase of $1 \times 10^{14} \mathrm{~cm}^{-2} / \mathrm{h}$ can be calculated from our ground based measurements. A similar result is obtained comparing ground based measurements carried out in the morning and GOME data. The retrieved a.m. columns of $\mathrm{NO}_{2}$ show roughly $25 \%$ lower values compared to the GOME results. In comparison to the ground based measurements, the total columns of $\mathrm{NO}_{2}$ from GOME are $4 \times 10^{14} \mathrm{~cm}^{-2}$ (mean value) higher because of its later overpass time of 10:30 a.m. at KCO compared to the ground based measurements carried out $4 \mathrm{~h}$ earlier. This increase of $1 \times 10^{14} \mathrm{~cm}^{-2} / \mathrm{h}$ compared to the output of a photochemical model (Sinnhuber et al., 2005) based on the chemistry scheme from the SLIMCAT model (Chipperfield, 1999), with reaction rate constants taken from the JPL-2002 recommendations (Sander et al., 2002) (see Fig. 3c) which predicts an increase of $8 \times 10^{13} \mathrm{~cm}^{-2} / \mathrm{h}$. This increase, which is almost linear during the times of ground based and GOME measurements (as can be seen from Fig. 3c), is in a good agreement with the result calculated from the ground based measurements $\left(1 \times 10^{14} \mathrm{~cm}^{-2} / \mathrm{h}\right)$. The interpolation of the retrieved a.m. and p.m. columns of $\mathrm{NO}_{2}$ from ground based measurements to the overpass time of GOME, depicted in blue in Fig. 3b, shows differences of around 3\% compared to the GOME results. In summary, both $\mathrm{O}_{3}$ and $\mathrm{NO}_{2}$ columns derived from GOME measurements agree well with the values obtained from the ground based measurements within their error bars. While for $\mathrm{O}_{3}$ no diurnal variation could be observed, $\mathrm{NO}_{2}$ significantly increases over the day in good agreement with results from a photochemical box model.

\subsection{Tropospheric column amounts of $\mathrm{O}_{3}$}

The second scientific aim of this study was to determine the influence of pollution events on the tropospheric column amounts of $\mathrm{O}_{3}$ and $\mathrm{NO}_{2}$.

Figure 4 shows the comparison between the tropospheric column of $\mathrm{O}_{3}$ determined as described above from GOME data and that derived from the ozone sonde measurements. The results of tropospheric amounts of $\mathrm{O}_{3}$ from both instruments are in the range of background conditions because the tropical Indian Ocean is dominantly influenced by pristine air masses from the southern Indian Ocean including Antarctica during this time of the year. The following comparison shows the results of two selected case studies, for which the atmospheric circumstances were especially favourable for the DOAS technique. They are depicted in red in Fig. 4 and show lower tropospheric ozone columns for the ground based DOAS data compared to the results of either GOME ( $40 \%$ ) or ozone sonde measurements ( $33 \%$ ) on these two days. The differences between the sonde data and the remotely sensed satellite data are within a range of $4 \%$ ( $1.2 \mathrm{DU})$. Taking into account the error bars of both the $\mathrm{O}_{3}$-sondes and satellite 
based data, during this episode the two instruments agreed within their error limits (see Fig. 4).

The reason for the differences in the values between ground based, satellite, and ozone sonde measurements is likely a combination of limitations arising from the DOAS ground based measurements. One of the main error sources is poorly known type and amount of aerosol. Following from the high amount of aerosol over the Indian Ocean, the use of the dual-axis-DOAS instrument, in contrast to the MAX (multi axis)-DOAS instruments (Wittrock et al., 2004), as used presently, can introduce large errors. The calculation of the tropospheric AMFs taking into account only two different observing modes (zenith-sky and off-axis) consequently leads to an overall uncertainty of the analysis with estimated errors on the order of $10 \mathrm{DU}$, a value usually expected for this type of study. Thus, within the combined error limits, the ground based measurements agree with the GOME results.

\subsection{Tropospheric column amounts of $\mathrm{NO}_{2}$}

In this study, in addition to the analysis of tropospheric $\mathrm{O}_{3}$, the influence of tropospheric pollution with respect to $\mathrm{NO}_{2}$ was determined. Using the high temporal resolution of ground based data, a localised tropospheric $\mathrm{NO}_{2}$ plume could be observed on 15 March 1999; on most of the days the tropospheric $\mathrm{NO}_{2}$ amounts did not significantly rise above the detection limit. An increase of the slant column of $\mathrm{NO}_{2}$ due to polluted air masses was observed in the off-axis mode first. The same polluted air mass was later transported through the zenith-sky telescope's field of view, and the slant columns of the zenith-sky measurements increased as well. After the air mass has passed the telescope, the slant columns of both observing modes were then decreasing back to the stratospheric background value. Based on the measurements of both observing modes, the increase and the following decrease of the $\mathrm{NO}_{2}$ slant columns can be determined as a function of time (see Fig. 5a). Using the wind speed in off axis direction $\left(\mathrm{v}_{\mathrm{W}}=\right.$ $5 \mathrm{~m} \mathrm{~s}^{-1}$ ), as measured at KCO), the elevation angle of the off axis viewing mode $\left(\alpha=2^{\circ}\right)$, the assumed vertical height of the plume $(\mathrm{h}=\mathrm{s} \times \tan (\alpha)=262 \mathrm{~m})$ with $\mathrm{s}=7500 \mathrm{~m}$ (the horizontal distance of the plume from the measuring point), its horizontal extension in the viewing direction ( $1=($ time of decrease of $\mathrm{SC}$ of both viewing modes - time of the first increase of SC of zenith data) $\times \mathrm{v}=900 \mathrm{~m}$ ) and its horizontal distance from the measuring point at a defined time (see Fig. 2) the tropospheric $\mathrm{NO}_{2}$ amount during a short pollution event can be obtained.

Dual-axis-DOAS reveals for the 15 March 1999 a maximum concentration of $1.2 \times 10^{11}$ molecules $\mathrm{cm}^{-3}$ ( $5 \mathrm{ppb}$ ) of $\mathrm{NO}_{2}$ based on the model assumption for a well mixed air mass over the Maldives (see Fig. 5b). On this day the observed total vertical column amount from ground based measurements was $1.8 \times 10^{15}$ molecules $\mathrm{cm}^{-2}$ (a.m. value, (see Fig. 3b). This means using the maximum concentra-

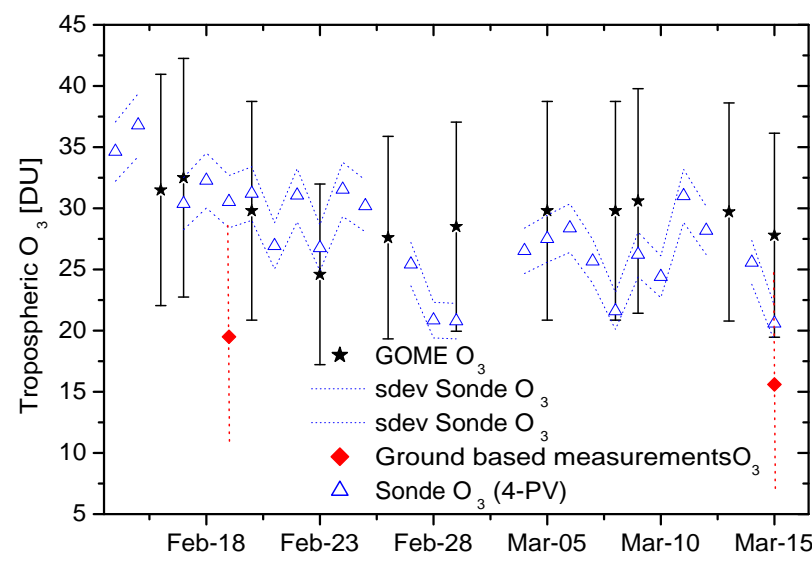

Fig. 4. Tropospheric columns of $\mathrm{O}_{3}$ measured by the ground based DOAS system compared with the $\mathrm{O}_{3}$-sondes and with GOME data for the time period of 14 February to 16 March 1999 during the INDOEX campaign.

tion of $1.2 \times 10^{11}$ molecules $\mathrm{cm}^{-3}$, a tropospheric vertical column amount for $\mathrm{NO}_{2}$ of $7.1 \times 10^{15}$ molecules $\mathrm{cm}^{-2}$ was determined. Therefore, on this day an increase by a factor of 4 occurred over Kaashidhoo during this brief pollution event (see Fig. 5b) for the total column amount of $\mathrm{NO}_{2}$.

Comparing this result with the tropospheric amount of $\mathrm{NO}_{2}$ measured with GOME for the same day, a difference of $6.1 \times 10^{15}$ molecules $\mathrm{cm}^{-2}$ can be observed (see Fig. $5 \mathrm{~b}$ ). This case study shows that a local increase of tropospheric $\mathrm{NO}_{2}$ up to $7.1 \times 10^{15}$ molecules $\mathrm{cm}^{-2}$ could be observed with ground based DOAS measurements in the afternoon whereas GOME measured $1 \times 10^{15}$ molecules $\mathrm{cm}^{-2}$ at 10:30 over this region. The difference between the two results is best explained by the strongly localised nature of the enhancement observed, both in space and time. For the large GOME pixel size, such a local event does not lead to a significant enhancement in tropospheric column. The different vertical sensitivity of the two measurement setups might also contribute, but given the good visibility on that day, the dilution effect alone can explain the results. Locally observed high values for tropospheric $\mathrm{NO}_{2}$ can be caused by different sources like combustion processes of anthropogenic or natural origin, such as biomass burning, and lightning discharge (Wayne, 1991). In this particular case, the increase of $\mathrm{NO}_{2}$ was probably caused by nitrogen oxide $\left(\mathrm{NO}_{\mathrm{x}}=\mathrm{NO}\right.$ $+\mathrm{NO}_{2}$ ) emissions from ships (Lawrence et al., 1999), (Kasibhatla et al., 2000), (Richter et al., 2004), (Wittrock et al., 2004). From GOME measurements the mean background tropospheric amount of $\mathrm{NO}_{2}$ was determined to be $4 \times 10^{14}$ molecules $\mathrm{cm}^{-2}$, while the mean total column amount of $\mathrm{NO}_{2}$ during the INDOEX campaign was $1.7 \times 10^{15}$ molecules $\mathrm{cm}^{-2}$ (both values for the above mentioned region of $300 \mathrm{~km}$ around $\mathrm{KCO}$ ). That means an average tropospheric fraction of $24 \%$ under clean air background conditions was observed. 

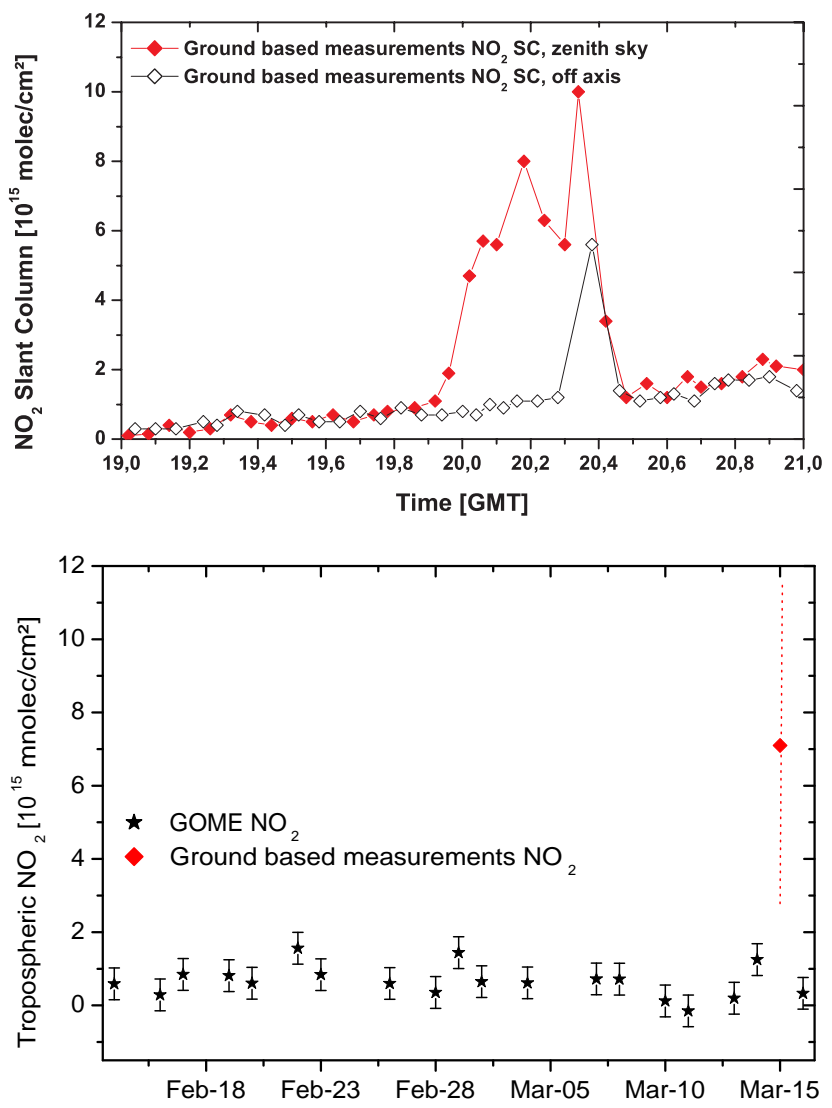

Fig. 5. Tropospheric slant columns of $\mathrm{NO}_{2}$ (a) measured by ground based (GB) DOAS system (off-axis and zenith-sky-data) for March 15, 1999. Tropospheric columns of $\mathrm{NO}_{2}$ (b) measured by ground based DOAS system and compared with tropospheric excess columns of GOME (GOME is only measuring at 10:30 a.m. and therefore not able to observe an enhancement of localised $\mathrm{NO}_{2}$ in the afternoon) for the time period of February 14 to March 16 1999 during the INDOEX campaign.

\subsection{Tropospheric column amounts of $\mathrm{BrO}$}

Tropospheric $\mathrm{BrO}$ has been positively detected over long periods of the year especially in polar spring in both hemispheres. These events have already been studied and compared with model output, balloon-borne observations and ground based measurements in previous publications (Wagner and Platt, 1998), (Richter et al., 1998), (Wagner et al., 2001), (Roozendael et al., 2002). They are attributed to boundary layer effects, in which photochemically produced active bromine can temporarily accumulate to high abundances in a shallow surface layer, consuming ozone while not being sequestered in chemically more stable bromine species. The source of $\mathrm{BrO}$ has not been identified beyond doubt but active bromine species are presumed to be released either from sea salt, especially in the form of frostflowers, or from biogenic organo-bromine species. In addition to the large values observed in polar spring, enhanced

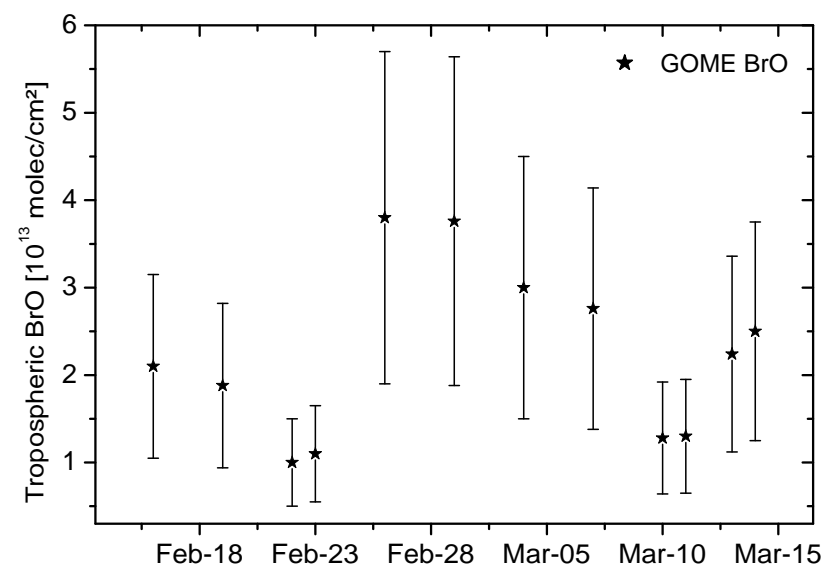

Fig. 6. Free tropospheric columns of BrO calculated from GOME data for the time period of February to March 1999 during the INDOEX campaign using the difference between "low cloud" and "high cloud" observations.

$\mathrm{BrO}$ is also observed globally in GOME data (Hegels et al., 1998), (Richter et al., 2002). This has tentatively been attributed to a significant background concentration of $\mathrm{BrO}$ in the free troposphere of several ppt, and direct evidence for $\mathrm{BrO}$ in the free troposphere was found by (Fitzenberger et al., 2000). Here, this assumption has been tested in the tropics by analysing ground-based DOAS measurements and satellite-based GOME data during the INDOEX campaign in the wavelength region $344-359 \mathrm{~nm}$ where BrO shows strong absorption features. Since several power failures have had an impact on the stability of the ground based instrument, only a detection limit of $3 \times 10^{14}$ molecules $\mathrm{cm}^{-2}$, was achieved for $\mathrm{BrO}$ from our ground based dual-axis-DOAS measurements. Using the difference of the slant columns of $\mathrm{BrO}$ retrieved at low (at 900-1013 mbar) and high cloud (at 0-600 mbar) situations during the INDOEX campaign an upper limit for the free tropospheric column of $\mathrm{BrO}$ of $3.8 \times 10^{13}$ molecules $\mathrm{cm}^{-2}$ from GOME (see Fig. 6) can be determined. Assuming a $4 \mathrm{~km}$ atmospheric layer at $1000 \mathrm{hPa}, 4 \mathrm{ppt}$ of $\mathrm{BrO}$ can be calculated for this time period. The value calculated in this study for the amount of tropospheric $\mathrm{BrO}$ during the campaign is representative for background conditions as estimated in other studies (Richter et al., 2002), (Wagner et al., 2001), (Pundt et al., 2002), (Fitzenberger et al., 2000) (Dickerson et al., 1999), (Roozendael et al., 2002).

\section{Conclusions}

During the INDOEX campaign in February and March 1999 on Kaashidhoo, ground based dual-axis DOAS measurements (zenith and off-axis-measurements) were performed in the equatorial region. This method provides information on total column as well as on tropospheric column amounts of $\mathrm{O}_{3}$ and $\mathrm{NO}_{2}$ and can distinguish between background 
and polluted atmospheric situations. In addition, an upper limit of $3.8 \times 10^{13}$ molecules $\mathrm{cm}^{-2}$ for the free tropospheric amount of $\mathrm{BrO}$ could be given by comparing measurements of GOME under high and low cloud situations. This abundance confirms previous studies. The comparison between ground based dual-axis DOAS, GOME (both detecting $\mathrm{O}_{3}$, $\mathrm{NO}_{2}, \mathrm{BrO}$ ), and $\mathrm{O}_{3}$-sonde data demonstrates that all measurement systems agreed within their error limits. The relatively large errors in the ground based data are related to the assumed homogeneity of the tropical air masses encountered. Differences between ground based and satellite measurements can result from the temporal variability of the atmosphere when measurements are not exactly coincident in time, and from the limited spatial resolution of GOME compared to ground based measurements. The dual-axisDOAS-technique and in addition the calculation of the different AMFs allowed to calculate around 19 DU for tropospheric $\mathrm{O}_{3}$ (two case studies on 19 of February and 14 of March 1999) and 263 DU for the total amount of $\mathrm{O}_{3}$. The results were compared to satellite based GOME-data and $\mathrm{O}_{3}$ sondes launched over Kaashidhoo. Differences of up to $40 \%$ for the GOME (24.6-32.5 DU) data and of 33\% for the $\mathrm{O}_{3}$ sonde measurements (20.6-36.8 DU) with respect to ground based results in the tropospheric part for both case studies were obtained; a discrepancy of 3\% for ground based and GOME data was observed for the vertical columns for the time period of the INDOEX campaign. Pollution events such as on 15 March 1999 could be detected by applying both, the zenith-sky and the off-axis mode of the ground based measurements of $\mathrm{NO}_{2}$. This demonstrates the ability of this measurement method to differentiate between local tropospheric emissions of, e.g., $\mathrm{NO}$ and stratospheric $\mathrm{NO}_{2}$ columns. A simple model based on a homogenous air mass with enhanced $\mathrm{NO}_{2}$-loading passing the two different observing modes yields an increase of up to $5-10 \mathrm{ppb}$ in this case study. GOME satellite data from the same day show no significant increase in $\mathrm{NO}_{2}$, highlighting the strengths and weaknesses of the two different observing systems. While GOME has excellent spatial coverage but limited spatial and temporal resolution and therefore limited sensitivity for the detection of localized events, the ground based measurements with the dual-axis-technique can observe local pollution events on a short time scale at one location. Furthermore, the above mentioned results for tropospheric $\mathrm{BrO}$ were made possible by the high spectral resolution and the comparably low detection limit of GOME for $\mathrm{BrO}$ in the tropical free troposphere. In the future additional campaigns should be carried out and also long term studies to confirm and extend the data set and our understanding of tropical pollution events.

Acknowledgements. Parts of this work have been funded by the University of Bremen, Germany, the DLR/DARA, the European Community, and the European Space Agency (ESA). We would like to thank H. Altmeyer who carried out with M. Bruns the measurements at KCO. We would like to thank R. B. A. Koelemeijer for providing the FRESCO data. We would like to thank the International sharing steering Group of the INDOEX campaign for great assistance, without which this work would not have been possible. We thank especially the organizers of the INDOEX campaign P. Crutzen and V. Ramanathan, J. Lobert and the whole KCO team during the IFP 1999. We thank in particular R. Dickerson for great help during the campaign. We also appreciate the warm hospitality of the Maldivians on the island Kaashidhoo, Republic of Maldives. Discussions with R. v. Kuhlmann, M. G. Lawrence and A. M. Thompson were very helpful.

Edited by: N. Mihalopoulos

\section{References}

Burrows, J. P., Dehn, A., Deters, B., Himmelmann, S., Richter, A., Voigt, S., and Orphal, J.: Atmospheric remote-sensing reference data from GOME: Part 1, Temperature-dependant absorption cross-sections of $\mathrm{NO}_{2}$, J. Quant. Spectrosc. Radiat. Transfer, 60, 1025-1031, 1998.

Burrows, J. P., M. Weber, M. Buchwitz, V. V. Rozanov, A. Ladstätter-Weißenmayer, A. Richter, R. de Beek, R. Hoogen, K. Bramstedt, K.-U. Eichmann, M. Eisinger and D. Perner, The Global Ozone Monitoring Experiment (GOME): Mission Concept and First Scientific Results, J. Atm. Sciences, 56, p. 151$175,1999$.

Chipperfield, M. P.: Multiannual simulations with a threedimensional chemical transport model, J. Geophys. Res., 104, 1781-1805, 1999.

Coldewey-Egbers, M., Weber, M., Lamsal, L. N., de Beek, R., Buchwitz, M., and Burrows, J. P.: Total ozone retrieval from GOME UV spectral data using the weighting function DOAS approach, Atmos. Chem. Phys., 5, 5015-5025, 2005, http://www.atmos-chem-phys.net/5/5015/2005/.

Dickerson, R. R., Rhoads, K. P., Carsey, T. P., Oltmans, S. J., Burrow, J. P., and Crutzen, P. J.: Ozone in the remote marine boundary layer: A possible role for halogens, J. Geophys. Res., 104, 21385-21 395, 1999.

Fitzenberger, R., Bösch, H., Camy-Peyret, C., Chipperfield, M. P., Harder, H., Platt, U., Sinnhuber, B. M., Wagner, T., and Pfeilsticker, K.: First Profile Measurements of Tropospheric $\mathrm{Br}_{O}$, Geophys. Res. Lett., 27, 2921-2925, 2000.

Grainger, J. F. and Ring, J.: Anomalous Fraunhofer line profiles, Nature, 193, 762, 1962.

Greenblatt, G. D., Orlando, J. J., Burkholder, J. B., and Ravisahankara, A. R. Absorption measurements of oxygen between 330 and 1140 nm, J. Geophys. Res., 95, 18 577-18 582, 1990.

Heckel, A., Richter, A., Tarsu, T. ,Wittrock, F., Hak, C., Pundt, I., Junkermann, W., and Burrows, J. P.: MAX-DOAS measurements of formaldehyde in the Po-Valley, Atmos. Chem. Phys., 5, 909918, 2005,

http://www.atmos-chem-phys.net/5/909/2005/.

Hegels, E., Crutzen, P. J., Klüpfel, T., Perner, D., and Burrows, J. P.: Global distribution of atmospheric bromine-monoxide from GOME on earth observing satellite ERS-2, Geophys. Res. Lett., 25, 3127-3130, 1998.

Hoenninger G., von Friedeburg, C., and Platt, U.: Multi axis differential optical absorption spectroscopy (MAX-DOAS), Atmos. Chem. Phys., 4, 231-254, 2004, http://www.atmos-chem-phys.net/4/231/2004/. 
Kasibhatla, P., Levy II, H., Moxim, W. J., Pandis, S. N., Corbett, J. J., Peterson, M. C., Honrath, R. E., Frost, G. J., Knapp, K., Parrish, D. D., and Ryerson, T. B.: Do emissions from ships have a significant impact on concentrations of nitrogen oxides in the marine boundary layer?, Geophys. Res. Lett., 27, 2229-2232, 2000.

Koelemeijer, R. B. A., Stammes, P., Hovenier, J. W., and de Haan, J. F.: A fast method for retrieval of cloud parameters using oxygen A-band measurements from GOME, J. Geophys. Res., 106, 3475-3490, 2001.

Komhyr, W. D., Barnes, R. A., Brothers, G. B., Lathrop, J. A., and Opperman, D. P.: Electrochemical concentration cell ozonesonde performance evaluation during STOIC 1989, J. Geophys. Res., 100, 9231-9244, 1995.

Ladstätter-Weißenmayer, A., Meyer-Arnek, J., Schlemm, A., and Burrows, J. P.: Influence of stratospheric airmasses on tropospheric vertical $\mathrm{O}_{3}$ columns based on GOME (Global Ozone Monitoring Experiment) measurements and backtrajectory calculation over the Pacific, Atmos. Chem. Phys., 4, 903-909, 2004, http://www.atmos-chem-phys.net/4/903/2004/.

Lawrence, M. G. and P. Crutzen,: Impacts of Oeangoing ship $\mathrm{NO}_{\mathrm{X}}$ Emission on Tropospheric Photochemistry, Nature, 402, 167170, 1999.

Lelieveld, J. P., Crutzen, J. and Ramanathan, V., et al.: The Indian Ocean Experiment: Widespread Air Pollution from South and Southeast Asia, Sience, 291, 1031-1036, 2001.

Leue, C., Wenig, M., Wagner, T., Klimm, O., Platt, U., and Jähne, B.: Quantitative analysis of $\mathrm{NO}_{\mathrm{x}}$ emissions from GOME satellite image sequences, J. Geophys. Res., 106, p. 5493-5505, 2001.

Lobert, J. M. and Harris, J. M.: Trace gases and air mass origin at Kasshidhoo, Indian Ocean, J. Geophys. Res., 107, D19, 8013, doi:10.1029/2001JD000731, 2002.

Martin, R. V., Chance, K., Jacob, D. J., Kurosu, T. P., Spurr, R. J. D., Bucsela, E., Gleason, J. F., Palmer, P. I., Bey, I., Fiore, A. M., Li, Q., Yantosca, R. M., and Koelmeijer, R. B. A.:, An improved retrieval of tropospheric nitrogen dioxide from GOME, J. Geophys. Res., 107(20), doi:10.1029/2001JD001027, 2002.

Platt, U.: Differential optical absorption spectroscopy (DOAS), in: Air Monitoring by Spectroscopic Techniques, Chem. Anal. Ser., edited by: Sigrist, M. W., John Wiley, New York, 127, 27-84, 1994.

Pundt, I., Pommereau, J.-P., Chipperfield, M. P., Van Roozendael, M., and Goutail, F.: Climatology of the stratospheric BrO vertical distribution by balloon-borne UV-visible spectrometry, , J. Geophys. Res., 107, D24, doi: 10.1029/2002JD002230, 2002.

Ramanathan, V., Crutzen, P. J., Lelieveld, J., Althausen, D., Anderson, J., Andreae, M. O., Cantrell, W., Cass, G., Chung, C. E., Clarke, A. D., Collins, W. D., Coakley, J. A., and Dulac, F.: The Indian Ocean Experiment: An integrated assessment of the climate forcing and effects of the great Indo-Asian haze, J. Geophys. Res. 106, (D22), 28371-28 398, 2001.

Richter, A., Wittrock, F., Eisinger, M., and Burrows, J. P.: GOME observations of tropospheric BrO in Northern Hemispheric spring and summer 1997, Geophys. Res. Lett., 25, pp. 2683-2686, 1998.

Richter A. and Burrows, J. P.: Retrieval of tropospheric $\mathrm{NO}_{2}$ from GOME measurements, Adv. Space Res., 29, 11, 1673-1683, 2002.

Richter, A., Wittrock, F., Ladstätter-Weissenmayer, A., and Bur- rows, J. P.: GOME measurements of stratospheric and tropospheric BrO, Adv. Space Res. 29, 1667-1672, 2002a.

Richter, A., Eyring, V., Burrows, J. P., Bovensmann, H., Lauer, A., Sierk, B., and Crutzen, P. J.: Satellite Measurements of $\mathrm{NO}_{2}$ from International Shipping Emissions, Geophys. Res. Lett., 31, L23110, doi:10.1029/2004GL020822, 2004.

Van Roozendael, M., Wagner, T., Richter, A., Pundt, I., Arlander, D. W., Burrows, J. P., Chipperfield, M., Fayt, C., Johnston, P. V., Lambert,J.-C., Kreher, K.,Pfeilsticker, K., and Platt, U., Pommereau, J.-P., Sinnhuber, B.-M., Toernkvist, K. K., and Wittrock, F.: Intercomparison of BrO Measurements from ERS-2 GOME, ground-based and Balloon Platforms, Adv. Space Res., 29(11), 1661-1666, 2002.

Van Roozendael, M., Fayt, C., Post, P., Hermans, C., and Lambert, J.-C.: Retrieval of $\mathrm{BrO}$ and $\mathrm{NO}_{2}$ from UV-Visible Observations, in: Sounding the troposphere from space: a new era for atmospheric chemistry, Springer-Verlag, ISBN 3-540-40873-8, edited by: Borell, P., Borell, P. M., Burrows, J. P., Platt, U., 2003.

Rothman, L. S., Gamache, R. R., Tipping, R. H., Rinsland, C. P., Smith, M. A. H., Benner, C. D., Devi, V. M., Flaud, J. M., CamyPeyret, C., Perrin, A., Goldman, A., Massie, S. T., and Brown, L. R.: The HITRAN molecular database editions 1991 and 1992, J. Quant. Spectrosc. Radiat. Transfer, 48, 469-507, 1992.

Rozanov, V., Diebel, D., Spurr, R. J., and Burrows, J. P.: GOMETRAN: A radiative transfer model for the satellite project GOME - the plance parallel version, J. Geophys. Res., 102, 16683$16695,1997$.

Sander, S. P., Friedl, R. R., Golden, D. M., et al.: Chemical kinetics and photochemical data for use in atmospheric studies, JPL Publ. Jet Propul. Lab., Pasadena, Calif. 0225, 335 pp., 2002.

Sinnhuber, B.-M., Rozanov, A., Sheode, N., Afe, O. T., Richter, A., Sinnhuber, M., Wittrock, F., Burrows, J. P., Stiller, G. P., von Clarmann, T., and A. Linden: Global observations of stratospheric bromine monoxide from SCIAMACHY, Geophys. Res. Lett., 32, L20810, doi:10.1029/2005GL023839, 2005.

Solomon, S. A. L., Schmeltekopf, and Sanders, W. R. : On the interpretation of zenith sky absorption measurements, J. Geophys Res., 92, p. 8311-8319, 1987.

Thompson, A. M., Witte, J. C., McPeters, R. D., Oltmans, S. J., Schmidlin, F. J., Logan, J. A., Fujiwara, M., Kirchhoff, V. W. J. H., Posny, F., Coetzee, G. J. R., Hoegger, B., Kawakami, S., Ogawa, T., Johnson, B. J., Vmel, H., and Labow, G.: Southern Hemisphere Additional Ozonesondes (SHADOZ) 1998-2000 tropical ozone climatology. 1. Comparison with Total Ozone Mapping Spectrometer (TOMS) and ground-based measurements, J. Geophys. Res., 108, art. no. 8238, doi:10.1029/2002JD002241, 2003.

Vountas, M., Rozanov, V. V., and Burrows, J. P.: Ring Effect: Impact of Rotational Raman Scattering on Radiative Transfer in Earth's Atmosphere, J. Quant. Spectrosc. Radiat. Transfer, 60, 943-961, 1998.

Wagner, T. and U. Platt: Satellite mapping of enhanced BrO concentrations in the troposphere, Nature, 395, 486-490, 1998.

Wagner, T., Leue, C., Wenig, M., Pfeilsticker, K., and Platt, U.: Spatial and temporal distribution of enhanced boundary layer $\mathrm{BrO}$ concentrations measured by the GOME instrument aboard ERS2, J. Geophys. Res., 106, 24 225-24 236, 2001.

Wayne, R. P.: Chemistry of Atmospheres, p. 565-566, 3rd Edition, Oxford 2000. 
Weber, M., Lamsal, L. N., Coldewey-Egbers, M., Bramstedt, K., and Burrows, J. P.: Pole-to-pole validation of GOME WFDOAS total ozone with groundbased data, Atmos. Chem. Phys., 5, 1341-1355, 2005,

http://www.atmos-chem-phys.net/5/1341/2005/.
Wittrock, F., Oetjen, H., Richter, A., Fietkau, S., Medeke, T., Rozanov, A., and Burrows, J. P.: MAX-DOAS measurements of atmospheric trace gases in Ny-Alesund, Atmos. Chem. Phys., 4, 955-966, 2004,

http://www.atmos-chem-phys.net/4/955/2004/. 